FTAMP 03.20.00

\author{
Жарқынбаева P.С. ${ }^{1}$, Абдирайымова А.С. 2 \\ ${ }^{1}$ тарих ғылымдарының докторы, профессор, әл-Фараби атындағы \\ Қазақ ұлттық университеті, Қазақстан, Алматы қ., e-mail: r_seidali@mail.ru \\ ${ }^{2}$ тарих ғылымдарының кандидаты, доцент, \\ М. Тынышбаев атындағы Қазақ көлік және коммуникация академиясы, \\ Қазақстан, Алматы қ., e-mail: ard_69@mail.ru

\section{ҚАЗАҚСТАНҒА ҰАЫ ОТАН СОҒЫСЫ КЕЗІНАЕ ҚОНЫС АУААРҒАН ХААЫҚТАРАЫҢ ӘАЕУМЕТТІК-ЭКОНОМИКААЫК ЖАҒААЙЫ}

\begin{abstract}
Ұлы Отан соғысы кезінде майдан өтіндегі халықтарды тылға, қауіпсіз жерге қоныс аудару үАерісі жалпылама жүргізілді. Осы үдерістің ең басты орталығы - Орта Азия, оның ішінде Қазақстан болған болатын. Аталмыш мақалада Қазақстанның Ұлы Отан соғысы кезіндегі қазақ жеріне қоныс аударған халықтардың әлеуметтік-экономикалық жағдайы сипатталған. Сол кездегі мұрағатта сақталған құжаттарға негізделе отырып, мақалада қоныс аударушылардың тұрмыстық қиындықтары, азық-түлік және тұрғын үй мәселелеріне зерттеу жүргізілген. Бұл зерттеу тек көшіп келушілер ғана емес, жалпы сол кездегі республиканың жағлайына бағытталған. Әскери жағдай кезіндегі бейбіт тұрғындар мен көшіп келушілердің жалпы қатынасына да тоқталған. Қоныс аудару жұмыстары соғыс кезінде жүргізілгендіктен өте қиын және қатаң жағдайда жүргізілді. Бұл кезеңде, ең алдымен жағдайды жасауға емес, жылдам уақытқа негізделді. ҚазКСР басшылығы орналастыру жұмысын қадағалап, дұрыс жүргізуге тырысқанымен, жергілікті жердегі калрлардың жетіспеуі, материалдық шығындардың орнын толтыратын қаржылай көмектің болмауы көші-қон мәселесінде көптеген мәселелер туындатып, жеткілікті жағдайда көмек көрсете алмады.
\end{abstract}

Түйін сөздер: Ұлы Отан соғысы, Қазақстан, миграция, эвакуация, майдан, тыл, күнделікті өмір.

\author{
Zharkynbayeva R.S. ${ }^{1}$, Abdiraiymova A.S. ${ }^{2}$ \\ 'Doctor of Historical science, Professor, al-Farabi Kazakh National University, \\ Kazakhstan, Almaty, e-mail: $r$ seidali@mail.ru \\ ${ }^{2}$ Candidate of historical science, Associate Professor, M. Tynyshpayev Kazakh Academy \\ of Transport and Communications, Kazakhstan, Almaty, e-mail: ard_69@ mail.ru
}

\title{
Social-economic situation of the evacuated population in Kazakhstan during the Great Patriotic war
}

The Great Patriotic War led to mass evacuation of the civilian population to logistic areas. Kazakhstan became one of the largest centers of accommodation of the evacuated population, the industrial enterprises, the cultural and educational organizations. The difficulties and problems which faced as the evacuated population, and local population and republican authorities are analyzed in the article; questions, connected how the population reacted to evacuation and a military situation and as they interacted with evacuated are considered. Location, employment and adaptation of the evacuated population took place in extremely severe conditions of wartime. The leaders of the Kazakh SSR tried to control process of location and creation for the evacuated population of acceptable living conditions, fought against the heartless attitude towards their needs and applied severe measures of party collecting, however a lack of resources, material and human, did not give it to make in due to volume. The research is based on archival documents, normative legal acts of wartime.

Key words: Kazakhstan, Great Patriotic War, migration, evacuation, front, back, mobilization, everyday life. 


\author{
Жаркынбаева Р.С. ${ }^{1}$, Абдирайымова А.С. ${ }^{2}$ \\ ${ }^{1}$ Аоктор исторических наук, профессор, Казахский национальный университет \\ имени аль-Фараби, Казахстан, г. Алматы, e-mail: r seidaliemail.ru \\ ${ }^{2}$ кандидат исторических наук, доцент, Казахская академия транспорта и коммуникаций,
} Казахстан, г. А^маты, e-mail: ard_69@ mail.ru

Социально-экономическое положение эвакуированного населения в Казахстан в годы Великой Отечественной войны

\begin{abstract}
Великая Отечественная война привела к массовой эвакуации гражданского населения в тыловые районы. ОАним из крупных центров размещения эвакуированного населения, промышленных преАприятий, культурных и образовательных организаций стал Казахстан. В статье анализируются трудности и проблемы, с которыми столкнулись как эвакуированное население, так и местное население, и республиканские органы власти; рассмотрены вопросы, связанные с тем, как население реагирова^о на эвакуацию и военную обстановку и как они взаимодействовали с эвакуированными. Размещение, трудоустройство и адаптация эвакуированного населения проходило в чрезвычайно суровых условиях военного времени. Руководство Казахской ССР пыталось контролировать процесс размещения и создания А^я эвакуированного населения приемлемых условий жизни и применяло жесткие меры партийного взыскания, однако нехватка ресурсов, материальных и человеческих, не давала это слелать в должном объеме. Исследование базируется на архивных документах, нормативно-правовых актах военного времени.
\end{abstract}

Кмючевые слова: Казахстан, Великая Отечественная война, миграция, эвакуация, фронт, тыл, повседневная жизнь.

\section{Kipicпе}

Соғыс тарихының негізгі деректері құрамындағы ең маңыздылары - соғыс ардагерлерінің, тыл қызметкерлері мен майдандағы әскери шенділер жазбалары, әскери операциялардың өту барысындағы жазылған құжаттар, бейбіт халықтардың естеліктері, т.б. бар. Iрі, үлкен көлемді территорияны қамтитын соғыстар қалай болмасын жергілікті халықтың барлық өміріне әсер етеді.

Қазіргі соғыс тарихының басты мәселелері ретінде, бейбіт халықтың экономикалық өмірі, әлеуметтік жағдайы, қоғамдық мінез-құлықтың өзгеруі мен мәдени араласулар, әскерге шақырту, соғыстан кейінгі жалпы жағдайды түзету барысында халықты жұмылдыра білу, т.б. мәселелерді шешу жолдарын атап өте аламыз. Осы сұрақтардың кеңінен зерттелуі - тарихтың ақтаңдақ беттерін ашуға, талас тудыратын тұстарына толыққанды жауап беруге көмегін тигізетінін атап көрсете отырып, тарихшылардың алдында тұрған іргелі мәселелердің бірі екенін де ұмытпауымыз қажет.

Соғыс тарихы - бұл, тек қана әскери ісәрекеттердің қалай жүргені ғана емес, сонымен қатар сол соғысқа еріксіз араласқан бейбіт тұрғындардың қоғамдық тарихы.

Қазіргі кезде, Ұлы Отан соғысы кезінде тылда және майдан өтінде ерлік көрсетіп, «барын майданға, барлығын жеңіске» арнаған жергілікті кеңес халқының осынау ерен еңбегін одан ары тереңдеп зерттеп, ақтаңдақ тұстарын ашып көрсетіп, толыққанды зерттеу жүргізу өзекті мәселердің қатарында екені анық.

\section{Методологиялық бөлімі}

Біз бұл мақалада тарих ғылымында көптеп қолданылатын салыстырмалы-тарихи әдісті, уақыт бойынша жүйелейтін - мерзімдемелік әдісті және жалпы қорытынды шығаруға көмектесетін - логикалық пен жүйелілік әдістерді, салыстырмалы-тарихи, нақты-тарихи, сараптау, уақыттық-мәселелік, әлеуметтік-психологиялық әдістеріне де кеңінен қолданамыз.

Сонымен қатар, мұрағаттық құжаттар болғандықтан тарихи көмекші пәндермен пәнаралық байланыс кенінен қолданылады.

Күштеп қоныс аударған халықтардың әлеуметтік жағынан қарастыратын мәселелері жеткілікті. Әскери кезеңнің жағдайына ене отырып, сол кездегі мәселелерді тереңірек зерттеу үшін бізге мұрағат құжаттары өте көп көмегін тигізеді. Бүгінгі зерттеу мақаласында үлкен деректер қорын Қазақстан Республикасы президенті мұрағатының жеке қорындағы істер, атап айтсақ, 708, 725 қорларының деректері және Ұлттық мұрағат қорының 79 қорының құжаттары үлкен көмегін тигізеді.

Көшіп келушілердің әлеуметтік мәселесін тарихи құжаттар арқылы қарастыру - сол кездегі қоныс аударған халықтардың басынан кешкен қиындықтары, аштық пен суықты көрген басқа 
ұлттардың қазақ халқымен тығыз байланысқа қалай түскенін түсінуге болады.

\section{Негізгі бөлім}

Ұлы Отан соғысы - қазақ жеріне жан-жақтан мыңдаған адамдардың қоныс аударуына себеп болды. Жалпы Кеңес өкіметі соғыс кезінде майданға жақын аймақтардан шығыс және орталық өңірлерге 17 млн. адамды көшірген болатын (Куманев Г.А., 2006).

1941-1942 жылдары КСРО-да - жүзеге асқан жалпыхалықтық қоныс аудару шынымен де тарих сахнасындағы ең үлкен оқиғалардың бірі еді. Қамту аймағы мен жүргізілу кезеңдері және қандай жағдайда жүргізілгені тарих беттерінде мұрағат деректерінде көптеп сақталып қалған болатын. Соғыс басталған соң бес күн өткеннен кейін «Бағалы мүліктер мен адам санын шығару және орналастыру» туралы КСРО ХКК БКП (б) ОК қаулысы шығып, көші-қон туралы кеңес құрылып, ол кеңестер көшірудің кезегін, бағытын және адам санын анықтаған болатын.

1941 жылдың 24 маусымында Л.М. Каганович басқаратын эвакуация жөніндегі Кеңес құрылды. Халықты және өнеркәсіп кәсіпорындарын эвакуациялау Бүкілресейлік (б) Коммунистік Партияның Орталық Комитетінің және КСРО-ның Халық Комиссарлары Кеңесінің «Адам контингенттерін шығару мен орналастыру тәртібі туралы» 1941 жылғы 27 маусымдағы Қаулысына сәйкес жүргізілді. Аталған қаулыға сәйкес төменде атап көрсетілгендер бірінші кезекте эвакуациялануы тиіс болды:

a) маңызды өнеркәсіптік құндылықтар (құрал-жабдықтар - маңызды станоктар мен машиналар), бағалы шикізат ресурстары мен өнеркәсіп заттары (түсті металдар, жанаржағармай, нан) және мемлекет үшін маңызы бар басқа да құндылықтар;

б) «майданнан қоныс аударушылар кәсіпорындармен бірге білікті жұмысшылар, инженерлер және қызметкерлер, бірінші кезекте әскери қызметке жарамды жастар, жауапты кеңес және партия қызметкерлері» (Известия ЦК КПСС,1990).

Аталмыш құжаттардан көрініп тұрғанындай, кеңестік мемлекеттің құндылықтық иерархиясында соғыс уақытында материалдық құндылықтардың маңыздылығы бірінші орында тұрды, ал адам ресурстары, соның ішінде әскери экономика мен номенклатураға пайдасын тигізе алатын адамдар екінші орында тұрды. Нәтижесінде бұл өнеркәсіп кәсіпорындарын орналастыру мен өндірісті реттеудің бірінші кезектегі міндетке айналғандығын көрсетті. Бұл шара елдің негізгі экономикалық базасын сақтау үшін және өнеркәсіпті соғысқа арналған әскери өнімдер үшін өте қажетті жаппай шығарылымға бағыттап құру үшін қажет болды. Алайда, халықтың эвакуациясы негізгі басымдықтардың қатарында болуы тиіс еді.

1941 жылы қазақ жеріне көшкен халықтардың мәселесін шешу үшін - ҚазКСР ХҚК қасынан М. Әбдіхалықов басқарған қоныс аударушылар бөлімі құрылды. Осы жылы күзден бастап қазақ жерінде «Қоныс аударушылар бойынша өкілетті бөлім» жұмыс жасай бастады. Бұл бөлім соғыс кезі болғандықтан тікелей Мемлекеттік Қорғаныс комитетіне бағынышты болды (История Казахстана, 2009:462). Негізінде көшіп келетін халықтардың тамағы мен медициналық көмегін ұйымдастыру дұрыс жолға қойылғанымен, адам ресурстарының жеткіліксіздігінен толыққанды жүзеге асқан жоқ.

Адамдарды көшіру барысындағы ең бірінші қателік - көшіру техникасында болды. Адам таситын вагондар мен арнайы поездардың болмауы, қоныс аударушылардың жүк вагондарымен және эшелондармен тасымалдануы ауру санын көбейтті. Ешқандай жағдай жасалмаған, тар, жарығы өте аз, көмескі және бұрын әртүрлі жүктер тасымалдаған вагондардың санитарлық тазалықтан өтпеуі жағдайды ушықтырып жіберді.

Соғыс кезіндегі Қазақстан КП ОК хатшысы Н. Скворцов 1941 жылдың қараша айында орталықтан арнайы жарлық алды. Ол бойынша, қоныс аударушылар арасынан көптеген арыздар түсіп жатыр, кейде кейбір станцияларда бес тәулікке дейін тұрып қалады, ыстық тамақтан тек қайнаған су ғана беріледі, медициналық көмек жоқтың қасы, ал жергілікті билік оларға теріс көзқараспен қарайды деген қорытынды жасалған (АП РК. Ф.725; Оп.4, д.725, л.17).

Орталық барлық партия өкілдеріне осы мәселені қолға алып тезірек шешуге тапсырма берген болатын. Қоныс аударушылардың жағдайын бақылауда ұстауға, тоқтаған жерінде медициналық көмек көрсету және ыстық тамақпен қамтамасыз ету үшін әрбір станцияларда арнайы топ құрылу қажеттігі айтылады. Адамдар тиелген эшелондар ең аз дегенде тәулігіне бес жүз-алты жүз шақырым жүріп өту керек. Оның үстіне поездан қашып кеткендер мен кешігіп қалғандарды екінші және үшінші кезектегі поездарға салып жіберу қатаң тапсырылған. 
Қоныс аударушыларға аянышты қарап, кейде «масыл болатын болды-ау» деген көзқарастар басым болып, көшіп келушілер психологиялық жағынан күйзеліске ұшырады. Олар кейде көздеген жеріне жете алмай, әртүрлі станцияларда немесе эвокобекеттерде ұзақ тұрып қалған болатын. Кейбір көзі ашық қоныс аударушылар жергілікті билікке шағым жасап, газетжурналдарға мақалалар шығарған болатын.

Жалпы осы мәселе бойынша батыс зерттеушілерінің еңбектерінде жақсы көзқарастар берілген. Атап айтсақ, шет елде жарыққа шыққан зерттеулерде, «Орта Азияға қоныс аударған адамдардың жергілікті халықпен сіңісіп кетуіне, біріншіден, психологиялық және өмір сүру салты бойынша ерекшеліктер әсер етсе, екіншіден, бұл мәселенің экономикалық жағдайына баса назар аударылған. Азық-түліктің жетіспеуі және теміржол инфрақұрылымының нашар жұмыс жасауы қоныс аудару үдерісін қиындата түсті... » (Manley R., 2009).

Ұлы Отан соғысына арналған келесі бір шетелдік еңбекте, қоныс аудару мәселесі мен жалпы соғыс барысында әйел азаматтардың ерен еңбегі жайлы баяндала келе, тылдағы жалпы жағдайдың тұрақталуына тигізген әйелдердің көмегі кеңінен талданған (Krylova A., 2010).

Мұндай еңбектерді оқи отырып, көшіп келген халықтардың басты мәселелері қатарында, ең алдымен орналасуы болғанын көреміз. Қоныс аударушылардың басым көпшілігі аудан немесе облыс орталықтарында орналасып қалуға тырысқан болатын. Кейбіреулері аудан орталығынан алыс белгісіз ауылдарға барудан бас тартты.

Соғыс кезіндегі қарапайым халықтардың еңбектерін ашып көрсету үшін, ең алдымен үш бағыттағы деректерді ғылыми айналымға енгізу қажет. Біріншіден, мұрағатта сақталған құжаттардың дұрыс берілуі, яғни деректі сол күйінде аударып бере салмай, дерекке тарихи сараптама жасау керек.

Екіншіден, соғыс кезіндегі жеке адамдардың жазбалары (күнделіктер, еске алулар, мемуарлар, естеліктер) субъективті бағытта болса да, сол кезеңдегі жалпы қоғамдық өмірді сипаттауға үлкен көмегін тигізеді.

Үшіншіден, соғыс ардагерлері мен тыл қызметкерлерімен жүргізілген жеке сұхбаттардың ғылыми маңыздылығын атап көрсетуіміз керек.

Осы үш бағыттағы деректерді жақсы пайдалана отырып, өз еңбектерін жазған британ соғыс тарихшысы С. Хейтингс әртүрлі адамдардың құжаттарын, естеліктері мен күнделіктерін ғана пайдалана отырып, соғыстың бүкіл қорқынышты да қасіретті жақтарын жақсы ашып көрсеткен.

Соғыс уақытында қоныс аудару үдерісін екі рет жүргізуге тура келді. Біріншісі, жалпы қоныс аудару - 1941 жылдың жазы-күзі; Екіншісі 1942 жылдың жазы-күзі.

Қазақстан аумағы қоныс аударушылар үшін үлкен екі аймаққа бөлінді; 1. Солтүстік және шығыс аудандар; 2. Оңтүстік және орталық аудандар.

Б. Жангутиннің зерттеуі бойынша 1941 жылдың тамызы мен 1942 жылдың қаңтар айы аралығында ҚазКСР-ға 24258 адам қоныс аударды. Олардың ішінде, РСФСР - 10000 астам, Украинадан - 6000 астам, Белорус жерінен 5000 астам, Литвадан - 200 астам, Қрымнан 11000 астам, басқа да өңірлерден - 1000 астам адам қоныс аударды. Егер этникалық құрамына көңіл аударатын болсақ, 10000 астам орыс, 2000 астам украин, 1000 астам - белорус, 8000 астам - еврейлер, 150 астам - поляк, 100 астам - неміс, латыш, эстон, т.б. бар. 60 пайыздан астамы әйел адамдар, 30 пайыздан астамы - балалар және ер азаматтар еді. 1942 жылдың қаңтарында - қоныс аударушылардың жалпы саны - 300000 асып жығылды. Ал, қаңтар айынан кейін жағдай біршама түзеліп, қоныс аударушылардың жалпы саны жарты жылда - тек 30 000-ға ғана жуық болды. (Жангутин Б., 2005).

Қазақстан жеріне көшіру үшін бірнеше факторлар әсер еткен болатын. Атап айтсақ, біріншіден, географиялық орналасауы - яғни, Қазақ жері соғыс майданынан қашықта орналасқан. Екіншіден, экономикалық жағдай. Соғыс алдында республиканың табиғи байлықтары мен экономикалық әлеуетінің жоғары болуы, қазақ жеріндегі жағдайды Орталық өте жақсы деп қабылдаған болатын. Үшіншіден, қазақ жеріне тартылған теміржол байланысының маңызы өте зор болды. Орталықтан тоқтаусыз келетін теміржол байланысы көшіп келушілерді үлкен көлемде тасымалдауға жағдай жасады.

Қоныс аударушылардың тарихын ең біріншіден, батырлыққа толы, ерлікпен жүзеге асқан үдеріс деп қабылдасақ, екіншіден, шынымен де қасіретті тарихи оқиға болған болатын. Осы уақытқа дейінгі зерттеулерге көз жүгіртер болсақ, осы оқиғаны екі түрде бағалайды; 1. Көпұлттық ортаның қалыптасуы мен халықтардың достастығы туындаған өте зор үдеріс деп мадақтау болса, 2. Қоныс аударудың барысында жіберілген кемшіліктер мен жауапкершіліктің аз болуынан туындаған қасіретті жағдай болып саналады. 
Сол кездегі халықтың шынайы жағдайына қарасақ, шынымен де өте қиын жағдайда жүзеге асырылған осы үдерістің теріс жақтарының басым екенін көруге болады. Қолда бар мұрағат құжаттарына сүйене отырып, осындай шешім қабылдауға екі себеп бар екенін көре аламыз.

Жалпы саны - 300-ден астам әртүрлі ұлт өкілдерінің келуі және олардың кейіннен 85 \% қалып қалуы - қазіргі Қазақстанды көпұлтты мемлекет ретінде қарауға мүмкіндік жасады. Сол қоныс аударудың нәтижесінде, жалпы қоныс аударушылардың саны - 500 000-ға жуық болды. Олардың - 30\% қалалық жерде, 70\% ауылдық жерде өмір сүрді. Көшіп келгендердің арасында әйелдер мен балалардың жалпы үлестік салмағы 74,8\% болды (История Казахстана, 2009:463).

Соғыс отбасыларды өмір сүрген мекендерінен айырып, қорқынышты, түпсіз тұңғиыққа лақтырып тастады. Қоныс аударушылар халықты орналастыру, жұмыспен қамтамасыз ету және бейімдеу соғыс уақытында өте қатал жағдайларда жүргізілді. Қоныс аударушылар халықтың тылдағы аудандарға ағылып келуі, соның ішінде Қазақстанға келуі кадр тапшылығын тіптен шиеленістіріп жіберді және де қоныс аударушылар халықтың негізгі қажеттіліктерін қанағаттандыруға арналған материалдық құралдардың жетіспеушілігін туындатты.

Мысалы, 1943 жылы қоныс аударушылар халықтың шаруашылық құрылғылары жөніндегі бөліміне қоныс аударушылар халыққа ақшалай көмек көрсету үшін 2 млн. рубль қаржыға сұраныс жасалған, осы мақсаттарға 500 мың рубль бөлінген, яғни, қажетті сұралған суммадан 3 есе аз қаржы бөлінген ( АП РК. Ф.708; Оп.7/1, д.748, л.11-12).

Мұрағаттық мәліметтері бойынша 1943 жылы Алматы эвакопункті бойынша 34 штаттық бірлік қарастырылған болса, іс жүзінде тек 11 адам ғана жұмыс істеген; Акмола эвакопунктінде 25, жұмыс істегендері 2; Ақтөбеде - 26, жұмыс істегендері - 4; Шығыс Қазақстанда 25, жұмыс істегендері - 4; Гурьевте - 34, жұмыс істегендері - 3; Оралда - 26, жұмыс істегендері 6; Қостанайда-24, жұмыс істегендері - 7; Павлодарда - 25, жұмыс істегендері - 2; Петропавлда 28 , жұмыс істегендері - 2; Семейде - 26, жұмыс істегендері - 4 (АП РК. Ф.708; Оп.7/1, д.748, л.14). Сөйтіп, бөлінген 291 штаттық бірліктің орнына іс жүзінде барлығы 49 қызметкер ғана жұмыс істеген.

Үлкен проблема туындатқан тағы бір мәселе, қоныс аударушыларды орналастыру мен эше- лондарды уақтылы түсірмеу болды. Мысалы, Шу бекетінде қоныс аударушылар тиелген 12 вагон 1942 жылдың 19 қазанынан 25 қазанына дейін, яғни бір апта дерлік тұрып қалған. (АП РК. Ф.708; Оп.6/1, д.961, л.5).

Адамдардың көптеп шоғырлануы Қазақстанда жұқпалы аурулардың көбеюіне алып келді. Жұқпалы аурулардың алғашқы оқиғасы 1941 жылдың қыркүйек-қазан айларында поезда басталды. Осы уақыттан бастап Түркістан-Сібір темір жолында жолдардың ішкі ресурстары есебінен 460 қосымша эпидемиялық койкалар қойылды. (АП РК. Ф.708; Оп.6/1, д.976, л.66-69). Адамдар педикулезге тексерілді. Моншалардың, дезокамералардың жұмысы ақырын болса да жақсартылды. Қысқа мерзім ішінде ұзақ уақыттық оқшаулау камералары салынды, әрине, ағылып келіп жатқан адамдардың санын есепке алғанда бұлардың саны жеткіліксіз болды.

Қоныс аударушылар халықтардың эшалонмен келгендерінің арасында асқазан-ішек жұқпалы арулары таралып, осы аурумен ауырғандардың саны артты.

Қоныс аударушы халықтардың эшалонмен келгендерінің арасында асқазан-ішек жұқпалы аурулары таралып, осы аурумен ауырғандардың саны артты. Егер де, Павлодар облысында 1941 жылы 87 жағдай тіркелсе, 1942 жылы 656 жағдай орын алған.

Ең бір ауыр жағдайлардың бірі «Алматы станциясына келген Тельман ат. Отрож вагон-ремонт заводының құрылғылары мен адамдардың жай-күйі туралы анықтамада» орын алған. 1941 ж. 5 желтоқсанда Алматы 1 станциясына 24 вагон - 879 адам және 4 вагон материалдармен, құрылығылармен келіп, түсіре бастады. Келгендер вагонда тұра беруін жалғастырды, атап өтілгендей вагондарды қарау барысында адамдардың көпшілігі осы тар вагонда тұрған, олардың арасында ауру таралуы кездескен, әсіресе балалар арасында ауру таралған. 26 желтоқсанда, вагондарда 23 ауру адам болып, олардың көпшілігі балалар және олар дизентериямен ауырған (АП РК. Ф.725; Оп.4, д.194, л.116-118).

ВКП ОК хатшысы А.А. Андреев 1941 жылы 25 қарашада ҚазССР КП/б ОК хатшысы Н.А. Скворцовқа фронттық аудандардағы жұмысшылардың, қызметшілердің және колхозшылардың қоныс аударушыларға дұрыс емес қатынастың орын алғандығы туралы фактілердің келіп түскендігі туралы хат жазады.

Қоныс аударушылар орналасқан вагонды жанармаймен, азық-түлікпен және ыстық су- 
мен қамтамасыз ету, сонымен қатар санитарлық қызмет көрсету өте нашар ұйымдастырылған. Осыған байланысты жергілікті билік органдары «станциялардағы адамдар эшалонындағы басқа поездарды бөлу және оларға әскерилерден басқа поездар ішінде басымдықтар бере отырып, күндік 500-600 шақырым жол жүруін қамтамасыз ету» туралы ГКО қаулысын жүйелі түрде тексере отырып, «темір жолдарды бақылауына алуы» тиісті болған. Сонымен қатар, партиялық жұмысшылар станция эшалондарындағы әрбірін, қоныс аударушы халықты азық-түлікпен, санитарлық қызметпен және медициналық қызметпен, ыстық сумен, вагондарды жанармаймен және т.б. қамтамасыз етуді тексеруге міндетті болды (АП РК. Ф.725; Оп.4, д.725, л.17).

Қоныс аударушылардыорналастыру мәселесі де ерекше орында тұрды. Барлық кеңестік мемлекеттер үшін, соның ішінде Қазақстан үшін де соғысқа дейінгі жылдарда тұрғын үй жағдайы өте қиын жағдайда еді. Белгілі болғандай, КСРО халқының басым бөлігі коммуналкаларда тұрып, тұрғын үй жеткіліксіздігі мәселесі өте өткір болып тұрған еді. КСРО-ның тыл аудандарында қоныс аударушыларды жайғастыру үшін «тығыздау» тәжірибесі жалғасын тапты және стратегиялық мүдделермен байланысы жоқ отбасыларды қалалардан ауылдық аймақтарға қоныстандыру саясаты жүргізілді.

1942-1944 жж. бүтіндей алғанда эвакуацияланған өндірістердің жұмысшы және инженертехникалық жұмысшылардың бір бөлігіне 15,5 млн. шаршы метр тұрғын үй салып беру мүмкін болды. Ал қалғандарын жергілікті халықты тығыздандыру арқылы орналастыруға тура келді. Қалаларда және жұмысшылар қонысында бір тұрғынға қатысты аудан 5,3-тен 4,3-ке дейін, ал кей жерлерде 2,3-ке дейін қысқарды (История Казахстана, 2009:463).

Қоныс аударушы тұрғындардың негізгі гуманитарлық мәселелері жергілікті, сонымен қатар одақтас мемлекеттік билік органдарына жазған көптеген хаттарда көрініс тапқан. Қазақстан Республикасының Президентінің мұрағатында осындай хаттардың көпшілігі жинақталған.

Қоныс аударушыларға ауыртпалықты проблема ретіндегі көзқарас қалыптасты. Батыс Қазақстан облысында 1942 жылы кейбір аудандарда қоныс аударушыларға әлі де «жағымсыз» қарым-қатынас сақталынған. Құжаттарда аталып өткеніндей, «кейбір келімсектер жергілікті колхозшылардан бірнеше есе жақсы жұмыс атқарса да» оларға ауыртпалық ретінде қараған. (АП РК. Ф.725; Оп.4, д.412, л.124).

Қоныс аударушылардың экономикалық ахуалы олардың қалай көшірілгендігіне, олардың жоспарлы түрде болғанына немесе олардың өз еркімен көшкендеріне байланысты болды.

Белгілі болғандай, қоныс аударғандардың көпшілігі асығыс, 1941 жылы жазда немесе күздің басында жиналып, өздерімен тек жазғы киімдерін алған. Жылы киімдерінің болмауы, олардың балаларының мектепке, ал ересектерінің жұмысқа бара алмауына түрткі болады.

Тұрғын үй мәселесінен, дөрекіліктен басқа, жұмыстарды әділетсіз бөлгендігі туралы, жекелеген жағдайларда кейбір қоныс аударушылар жақсы орналасқандығына шағымдар болды.

Партиялық органдар жедел әрекет жасауға тырысты, оны №708 (Қазақстанның Орталық комитетінің) және №725 (Қазақ ССР партиялық бақылау комиссиясы) фондындағы бар құжаттарды сараптау барысында байқауға болады.

1942 жылдары жағдай қиындап, келген қоныс аударушылардың жағдайы тұрмақ, жергілікті халықтың ашығуы байқала бастады. Тамақтың тәуліктік көлемі азайып, 1943 жылы тіпті жоқтың қасында болды.

Атап айтсақ, 1943 жылдың жазына таман:

1. Бала-шаға тамақтың тәуліктік үлесінен алынып тасталды.

2. Берілетін азық-түлік көлемі азайды, мысалға, қант, нан көлемі.

3. 1943 жылдың жазында құрғақшылық болғандықтан, кейбір жерлерді жұмыс күніне берілетін азық-түлік тоқтатылды (АП РК. Ф.708; Оп.8, д.156, л.7).

Қоныс аударған халықтардың жағдайы 1943 жылдың аяғына қарай өте қиындап кетті. Мыңдаған адам аурудан, аштықтан, суықтан қайтыс болды. Ал көпшілігі адам тұрғысыз, жағдайы дұрыс жасалмаған ғимараттарда тұруға мәжбүр болды.

\section{Қорытынды}

Ұлы Отан соғысы жылдары қоныс аударушылар халық орналастыру мен елдің табиғиклиматтық жағдайларына бейімделуге қатысты үлкен қиындықтармен бетпе-бет келгендігін атап өту керек. Кей жағдайларда, өмірдің шаруашылық-тұрмыстық аспектілерімен байланысты жергілікті халық пен қоныс аударушылар арасында қақтығысқан жағдайлар да орын алды. 
Билік органдары, егер де қоныс аударушыларды мәжбүрлі түрде қоныстандырып, жайғастырудың жергілікті халық пен қоныс аударушылардың арасында «ынтымақты» көршілік байланыстың орнамайтындығына саналы түрде көздері жетті. Қазақстанда соғыс жылдары азаматтық құрылыс нысандары салынғанымен де шектеулі ресурстар, құрылыс материалдарының жеткіліксіздігі осы әрекеттерді жасауға мәжбүрледі. Гуманитарлық көмектің жеткіліксіздігі мен әділетті бөлінбеуі қоныс аударушылар арасында қарсылықтың өршуіне алып келді.

Қазақ жеріне қоныс аударған халықтардың алдында тұрған мәселелерге тоқтала отырып, сол кездегі қазақ халқының Кеңес өкіметіне көрсеткен орасан зор көмегін түсінуге болады. Осы кезде «қаншама қателіктер жіберді» деген күннің өзінде, сол кездегі биліктің қабылдаған шешімдері дұрыс бағытта болған. Кадрларды дұрыс пайдалану және көші-қон бағытының дұрыс жолға қойылуы - майдан өтіндегі мыңдаған адамның өмірін сақтап қалған болатын.

Жергілікті халықтар көшіп келген қоныс аударушыларға көбіне жаны ашып қарап, барынша көмек көрсетуге тырысты. Атап айтсақ, киім-кешек, төсек жабдықтары мен азық-түлік мәселесінде жергілікті халықтардың көмегі орасан зор болды. Сол кездегі ерекше атап көрсететін мысал, әскери қызметкерлердің жанұяларына көмек, әйелдер кеңесінің жұмысы, көмек көрсету орталығы мен жас балаларды қорғау мәселелерін шешуге бағытталған «айлық» көмекті айта аламыз.
Қазақстандағы эвакуацияны еске ала отырып, Кеңес Одағының екі дүркін Батыры, генерал-лейтенант, ұшқыш-космонавт В.А. Шаталов: «Петропавлда мен ұзақ уақыт бойы болмадым, бірақ менің сөзіме сеніңіз, осы уақыт аралығында мен өзімнің туған қаламды ризашылықпен еске алдым. Шын мәнінде менің өмірім қазақ жерімен ажырамастай байланыста. Осы жерде дүниеге келдім, қазақтар менің анам соңғы эшалонмен фашистер қоршаған Ленинградтан босап шыққанда мені өздерінің ұлдары сияқты қамқорлықпен асырады» деген естеліктер қалдырды (Казахстанская Правда, 1969).

2016 жылдың 1 наурызынан бастап Қазақстан Республикасы күнтізбесінде жаңа мейрам - «Алғыс күні» пайда болды. Бұл мерекенің басты мазмұны - көршілеріме, қасымдағы басқа ұлт өкілдеріне рахмет айту болып саналады. Әсіресе, Сталиндік кезеңдегі күшпен қоныс аударылған халықтардың қазақ халқына айтар алғысы көп. Аштық пен суықта келген әр жанұяға қазақ халқының көрсеткен көмегі, берген тамағы әлі күнге дейін басқа ұлт арасында үлкен құрметпен айтылады. Сондықтан да, көпұлтты мемлекет ретінде осындай ашық аспан мен бейбіт өмірде өмір сүріп отырған халқымыздың осы бағыттағы жұмыстарды қолдай беретініне сенімдіміз (Казахстан отмечает день благодарности..., 2018).

Мақ̧ала «Майдан/тыл: Қазақ̧стан мен Ресей тарихындагы Екінші дүниежүзілік/Ұль Отан согысының гендерлік аспектілері» атты іргелі жоба аясында дайындалды.

\section{Әдебиеттер}

АП РК. Ф.725; Оп.4, д.725, л.17.

АП РК. Ф.708; Оп.7/1, д.748, л.11-12.

АП РК. Ф.708; Оп.7/1, д.748, л.14.

АП РК. Ф.708; Оп.6/1, д.961, л.5.

АП РК. Ф.708; Оп.6/1,д.976, л.66-69.

АП РК. Ф.725; Оп.4,д.194,л.116-118.

АП РК. Ф.725; Оп.4, д.412, л.124.

АП РК. Ф.708; Оп.8, д.156, л.7.

Жангутин Б.О. Эвакуация советского населения в Казахстан (1941-1942 гг.) https://cyberleninka.ru/.../evakuatsiyasovetskogo-naseleniya-v-kazahstan-1941-1942

Известия ЦК КПСС, 1990. №6.С.208. О порядке вывоза и размещения людских контингентов и ценного имущества. Постановление ЦК ВКП(б) и СНК СССР. 27 июня 1941 г.

История Казахстана (с древнейших времен до наших дней) (2009). В пяти томах. Том 4. Алматы: Атамура,768 с.

Казахстан отмечает день благодарности. (2018) // http://assembly.kz/ru/news/kazahstan-otmechaet-den-blagodarnosti).

Казахстанская Правда. 1969, 27 апреля. Космонавт В.А. Шаталов в Петропавловске.

Куманев Г.А. Война и эвакуация в СССР. 1941-1942 гг. // Новая и новейшая история, 2006 . №6. С.7-27.

Krylova A. (2010). Soviet Women in Combat: A History of Violence on the Eastern Front. N.-Y.: Cambridge Univer-sity Press, $320 \mathrm{pp}$. 
Manley R. (2009). To the Tashkent Station: Evacuation and Survival in the Soviet Union at War. Ithaca: Cornell University Press, $282 \mathrm{pp}$.

Хейстингс М. (2015). Вторая мировая война: ад на земле: пер. с англ. - М.: Альпинанон-финиш, 689 с.

\section{References}

AP RK. F.725; Op.4, d.725, 1.17.

AP RK. F.708; Op.7/1, d.748, 1.11-12.

AP RK. F.708; Op.7/1, d.748, 1.14.

AP RK. F.708; Op.6/1, d.961, 1.5 .

AP RK. F.708; Op.6/1, d.976, 1.66-69.

AP RK. F.725; Op.4, d.194, 1.116-118.

AP RK. F.725; Op.4, d.412, 1.124.

AP RK. F.708; Op.8, d.156, 1.7.

Jangýtın B.O. Evakýatsıa sovetskogo naselenı1a v Kazahstan (1941-1942 gg.) [Evacuation of the Soviet population in Kazakhstan (1941-1942) ] https://cyberleninka.ru/.../evakuatsiya-sovetskogo-naseleniya-v-kazahstan-1941-1942

Izvestı1a TsK KPSS, 1990.№6. s.208.O porıdke vyvoza 1 razmeenı1a liýdskıh kontıngentov 1 tsennogo 1mýestva. Postanovlenıe TsK VKP(b) 1 SNK SSSR. [About the order of export and placement of human contingents and valuable property. The resolution of the Central Committee of the CPSU(b) and SNK]. 27 11ýnıa 1941 g.

Istorıa Kazahstana (s drevneıshı vremen do nashıh dne1) [History of Kazakhstan (from ancient times to the present day)]. (2009). V piatı tomah. Tom 4. Almaty: Atamýra,768 s.

Kazahstan otmechaet den blagodarnosti. [Kazakhstan celebrates the day of gratitude]. (2018) // http://assembly.kz/ru/news/ kazahstan-otmechaet-den-blagodarnosti).

Kazahstanska1a Pravda, 1969, 27 aprelıa. Kosmonavt V.A. Shatalov v Petropavlovske.

Kýmanev G.A. Voina 1 evakýatsı1a v SSSR. 1941-1942 gg. [War and evacuation in the USSR. 1941-1942]// Nova1a 1 nove1sha1a 1stor11a, 2006. №6.S.7-27.

Krylova A. (2010). Soviet Women in Combat: A History of Violence on the Eastern Front. N.-Y.: Cambridge Univer-sity Press, $320 \mathrm{pp}$.

Manley R. (2009). To the Tashkent Station: Evacuation and Survival in the Soviet Union at War. Ithaca: Cornell University Press, $282 \mathrm{pp}$.

Heistıngs M. (2015). Vtora1a mirova1a voina: ad na zemle. [All Hell Let Loose: The World at War 1939-1945]. Per. s angl. Moskva: Alpınanon-finısh, 689 s. 